\title{
Phytoprotection
}

\section{Policy and Regulations for Registration of Microbial Organisms in Canada}

\section{Wendy Sexsmith}

Volume 79, numéro 4, 1998

OECD Workshop - Sustainable Pest Management, Safe Utilization of New Organisms in Biological Control. Montréal, Québec, Canada. September 27-30, 1998.

Atelier de l'OCDE - Gestion durable des ennemis des cultures, Utilisation sécuritaire de nouveaux organismes de lutte biologique. Montréal, Québec, Canada. 27-30 Septembre 1998.

URI : https://id.erudit.org/iderudit/706147ar

DOI : https://doi.org/10.7202/706147ar

\section{Aller au sommaire du numéro}

\section{Éditeur(s)}

Société de protection des plantes du Québec (SPPQ)l

ISSN

0031-9511 (imprimé)

1710-1603 (numérique)

\section{Découvrir la revue}

\section{Citer cet article}

Sexsmith, W. (1998). Policy and Regulations for Registration of Microbial Organisms in Canada. Phytoprotection, 79(4), 3-4.

https://doi.org/10.7202/706147ar

\section{Résumé de l'article}

In Canada, microbial pest control products and agents are regulated under the Pest Control Products Act, administered by the Pest Management Regulatory Agency (PMRA) for the Minister of Health. A microbial includes bacteria, algae, fungi, protozoa, viruses, mycoplasmae or rickettsiae and related organisms. Microbial pest control products and agents can include those derived through genetic engineering. When the PMRA was established in 1995, specific directions were given by government to facilitate access to alternatives to traditional chemical products; to support environmental sustainability; and to pursue international cooperation to accelerate registration. Currently in Canada, there are 8 active ingredients and 34 products registered. In 1998, there were 19 research permits and notifications for active ingredients, an increase from 1997. Data requirements are set out in guidelines (Pro98-01 Regulatory Proposal: Guidelines for the registration of microbial pest control agents and products), rather than in regulation. General categories for data requirements for Tier 1 ( the set of information which is typically sufficient to allow regulators to determine that a product presents an acceptably low level of risk) include information or data on characterization, health toxicity, environmental toxicity, and efficacy. Pre-submission consultations between registrants and PMRA are encouraged. The main objectives of these consultations are to determine the appropriate study protocols and the subset of data requirements from the guidelines that may be required for the registration of a particular proposed product as well as the type of information required to support data waivers.

Key issues, questions and challenges regarding registration

1. Characterization of the microbial active ingredient is seen as critical and fundamental to the determination of the other data requirements both in environment and in health. The key components are:

- identification of the microorganism

- relationship to mammalian or other pathogens

- toxin producing potential

- manufacturing process, including potential for contaminants

- physical/technical properties, including storage stability.

2. Building on good information on characterization, for environmental risk assessment, information on host/target range, geographical distribution of host/target, and the geographical distribution of the microbial are key questions.

4. With respect to publicly-funded research groups, there is a need for links with commercial partners at an appropriate stage in order to love their products into the regulatory System and onto the marketplace. PMRA is working to support the registration and use of microbial products through developing data requirements appropriate to microbiais, working with growers and other stakeholders to support the implementation of Integrated Pest Management (IPM) strategies that include the use of microbials, harmonizing data requirements with both the US and other OECD countries, and ensuring the development of regulations and policies to encourage registration of these products
Ce document est protégé par la loi sur le droit d'auteur. L’utilisation des services d'Érudit (y compris la reproduction) est assujettie à sa politique d'utilisation que vous pouvez consulter en ligne.

https://apropos.erudit.org/fr/usagers/politique-dutilisation/ 


\title{
Policy and Regulations for Registration of Microbial Organisms in Canada
}

\author{
Wendy Sexsmith
}

Director, Alternative Strategies and Regulatory Affairs Division,

Pest Management Regulatory Agency, Health Canada,

2250 Riverside Drive, Ottawa, Ontario, Canada. K1A OK9

\section{ABSTRACT}

In Canada, microbial pest control products and agents are regulated under the Pest Control Products Act, administered by the Pest Management Regulatory Agency (PMRA) for the Minister of Health. A microbial includes bacteria, algae, fungi, protozoa, viruses, mycoplasmae or rickettsiae and related organisms. Microbial pest control products and agents can include those derived through genetic engineering.

When the PMRA was established in 1995, specific directions were given by government to facilitate access to alternatives to traditional chemical products; to support environmental sustainability; and to pursue international cooperation to accelerate registration.

Currently in Canada, there are 8 active ingredients and 34 products registered. In 1998, there were 19 research permits and notifications for active ingredients, an increase from 1997.

Data requirements are set out in guidelines (Pro98-01 Regulatory Proposal: Guidelines for the registration of microbial pest control agents and products), rather than in regulation. General categories for data requirements for Tier 1 ( the set of information which is typically sufficient to allow regulators to determine that a product presents an acceptably low level of risk) include information or data on characterization, health toxicity, environmental toxicity, and efficacy. Pre-submission consultations between registrants and PMRA are encouraged. The main objectives of these consultations are to determine the appropriate study protocols and the subset of data requirements from the guidelines that may be required for the registration of a particular proposed product as well as the type of information required to support data waivers.

Key issues, questions and challenges regarding registration

1. Characterization of the microbial active ingredient is seen as critical and fundamental to the determination of the other data requirements both in environment and in health. The key components are:

- identification of the microorganism

- relationship to mammalian or other pathogens

- toxin producing potential

- manufacturing process, including potential for contaminants

- physical/technical properties, including storage stability.

2. Building on good information on characterization, for environmental risk assessment, information on host/ target range, geographical distribution of host/target, and the geographical distribution of the microbial are key questions.

4. With respect to publicly-funded research groups, there is a need for 
links with commercial partners at an appropriate stage in order to move their products into the regulatory system and onto the marketplace.

PMRA is working to support the registration and use of microbial products through developing data requirements appropriate to microbials, working with growers and other stakeholders to support the implementation of Integrated Pest Management (IPM) strategies that include the use of microbials, harmonizing data requirements with both the US and other OECD countries, and ensuring the development of regulations and policies to encourage registration of these products.

\section{AN OVERVIEW}

The OECD's Pesticide Forum is one of ten sub-programmes of the OECD's Environmental Health and Safety (EHS) Programme. The Pesticide Forum focuses on both chemical and biological pesticides used in agriculture and other settings. Its goal is to help OECD countries share the work of pesticide risk assessment and find new approaches to risk reduction.

The Pesticide Forum has begun working to harmonize core data requirements (i.e., the basic studies required) for pesticide registration and use. Work has been proposed and is underway in a number of areas, including microorganisms. Harmonization of country data requirements would facilitate registration, reduce duplicate testing, and
A report prepared by the European Crop Protection Association (ECPA) supporting the harmonization of data requirements for micro-organisms and pheromones as a means to encourage the development of new environmentally friendly pest control products for sustainable agriculture was tabled at the February 1996 OECD Pesticide Forum. At the February 1998 Pesticide Forum, it was agreed that OECD countries, building on ongoing activities within both the European Union (EU) and US/Canada, should work together to develop common core data requirements for microbial pest control products. A Steering Committee was formed and a work plan developed. A meeting in Washington to compare country (Canada, the Netherlands, Sweden, United States (US)) approaches to data requirements was organized for August 1998, in order to provide input to the EU workshop planned for October 1998. The Steering Committee also agreed to participation in the OECD Cooperative Research Program workshop on Sustainable Pest Management: Safe Utilization of New Organisms in Biological Control.

A regulatory panel of representatives from Denmark, Sweden, Australia, the United States organized and chaired by Canada outlined the policies effecting the regulation of microorganisms, including genetically modified organisms, and supporting sustainable pest management; discussed experiences, regulatory approaches and general data requirements. Key issues, questions, and challenges were raised for discussion with the research community. 